\title{
SEDIMENT MORPHOLOGY AND DISTRIBUTION IN A RESTORED RIPARIAN FOREST
}

\author{
Renata Santos Momoli ${ }^{1}$; Miguel Cooper ${ }^{2 *}$; Selene Cristina de Pierri Castilho ${ }^{3}$ \\ ${ }^{1}$ USP/ESALQ - Programa de Pós-graduação em Solos e Nutrição de Plantas. \\ ${ }^{2}$ USP/ESALQ - Depto. de Ciência do Solo, C.P. 9 - 13418-900 - Piracicaba, SP - Brasil. \\ ${ }^{3}$ R. Pedro Morganti, 21 - Apto 34 - 04020-070 - São Paulo, SP - Brasil. \\ *Corresponding author <mcooper@esalq.usp.br>
}

\begin{abstract}
Sediment distribution patterns of riparian zones reflect the deposition dynamics and the type of deposition event. The purpose of this study is to characterize the morphology and distribution of sediments deposited in a restored riparian forest that were transported from adjacent areas cropped with sugar-cane. In order to study the deposition processes in a riparian forest located in the county of Iracemápolis state of São Paulo, Brazil, soil samples were collected on a transect for micromorphological as well as particle size distribution analyses, using Folk \& Ward statistical parameters. Soil samples were dispersed with $\mathrm{NaOH}+$ sodium hexametaphosphate and water. The dispersion in water was made to simulate field transport conditions. Particle size distributions together with field and laboratory morphological analyses showed an irregular and non-uniform sediment deposition. This deposition process suggests the occurrence of high intensity erosive events that produce high amount of sediments and runoff characterized by a turbulent flow. The land use change in the riparian area marks the change in the preferential deposition location, which when sugar-cane dominated, corresponded to the alluvial plain and, after the restoration and development of the riparian forest, was dislocated $27 \mathrm{~m}$ upslope within the first few meters from the border of the forest.

Key words: deposition, particle size distribution, image analysis
\end{abstract}

\section{MORFOLOGIA E DISTRIBUIÇÃO DOS SEDIMENTOS NUMA ZONARIPÁRIA REFLORESTADA}

\begin{abstract}
RESUMO: O padrão de distribuição de sedimentos na zona ripária reflete a dinâmica da deposição e os prováveis processos ocorridos. Para inferir sobre os processos de deposição ocorridos, amostras de solo foram coletadas numa transeção para a realização de análises micromorfológicas e, também análises granulométricas apoiadas na interpretação estatística dos parâmetros de Folk \& Ward (1957). As amostras de solo foram dispersas em $\mathrm{NaOH}+$ Hexametafosfato de Sódio e também em água, para simular as condições de transporte de sedimentos no campo. Os resultados obtidos através da análise granulométrica foram reforçados pelas análises de imagens e porosidade em amostras indeformadas. Os atributos do solo enterrado e dos sedimentos depositados evidenciam um padrão de deposição irregular e desuniforme, que sugere a ocorrência de eventos erosivos de grande intensidade (fluxo turbulento). Essa irregularidade e desuniformidade da deposição estão relacionadas à alteração do uso da terra. A implantação do reflorestamento na zona ripária de Iracema B deslocou a deposição de sedimentos, $27 \mathrm{~m}$ à montante na encosta.

Palavras-chave: deposição, granulometria, análise de imagens
\end{abstract}

\section{INTRODUCTION}

One of the most important causes of natural resource degradation is soil erosion. Its impact on natural resources can be on-site and off-site (Lal, 1998). Among the main on-site impacts, of importance are soil, water and fertilizer losses due to rainfall impact and runoff. Other on-site impacts that can be cited are the reduction in soil quality due to the reduction of soil depth available for plant rooting, reduction in the soil water retention capacity and soil organic carbon con- tent, and exposure of less fertile sub-superficial horizons. The main off-site impacts are environmental and include reduction of water quality of rivers and reservoirs, and air quality. Water quality is affected by silting, eutrophication and chemical pollution. Air quality is affected by the increase of soil particles in suspension in the air (dust) and emission of gases that can, for example, affect the greenhouse effect. Off-site impacts also affect agricultural productivity by favoring flooding of lowlands due to the accumulation of sediments, which bury the original soil. Other soil erosion 
off-site impacts also include impacts on engineering structures as building sites and urban areas.

The conservation of ecosystems is directly related to land use. The search for adequate land use tries to balance the necessities for natural resources preservation and for food and energy production. This has motivated various researchers to study conservation and management processes and techniques, which adequately adopted can reduce the impacts of human activities on ecosystems (Correll, 1997; Douglas, 1990; Lal, 1998; Rodrigues et al., 1992; Sparovek et al., 2002). Restoration of riparian forests can be considered an overall recuperation activity that focuses on soil and water conservation and preservation, as well as ecological aspects as the maintenance of fauna and flora diversities.

The purpose of this study is to characterize the morphology and distribution of sediments deposited in a riparian forest, transported from adjacent areas cropped with sugar-cane. The interpretation of this data is important for the understanding of the deposition dynamics and the filtrating capacity of restored riparian forests.

\section{MATERIAL AND METHODS}

The study area is situated in the riparian zone of the Iracema reserve located in the Ribeirão Cachoerinha watershed, Iracemápolis, SP, Brazil $\left(22^{\circ} 35^{\prime} \mathrm{S}\right.$ and $\left.47^{\circ} 31^{\prime} \mathrm{W}\right)$. A $35 \mathrm{~m}$ long transect that crosses a restored riparian forest was chosen, which extends up to the border of the reserve. The dominant soil of this transect is a Rhodic Hapludox (Soil Survey Staff, 1997) (Latossolo Vermelho distrófico, according to Embrapa, 2006). The restoration of the riparian forest with native species occurred in 1987 and has a mean width of $50 \mathrm{~m}$ bordering the entire reservoir (Rodrigues et al., 1992; 2004). The riparian forest is today at an advanced stage of development.

To characterize and evaluate the sediment distribution inside the riparian forest, detailed morphological studies were performed together with the physical characterization of soils and sediments. Twelve disturbed and 12 undisturbed soil samples were collected from 3 pits (T1, T2 and T3) and 36 disturbed soil samples were collected from auger holes located in the riparian forest (Figure 1). To characterize the soils that would be the potential contributors of sediments to the riparian forest, two auger holes in the sugar-cane field outside the studied transect (not shown in Figure 1) were also sampled. The bi-dimensional distribution of the soil horizons and sediments were determined using the methodology described by Boulet et al. (1982) and defined the location of the pits and auger holes. Complete morphological descriptions of the pits were made according to Lemos \& Santos (2002).

The disturbed soil samples collected from the pits and auger holes were oven dried at $105^{\circ} \mathrm{C}$ for 24 hours and sieved through a $2 \mathrm{~mm}$ sieve. Once homogenized the samples were dispersed in a solution of $\mathrm{NaOH}$ and sodium hexametaphosphate following the methodology proposed by Camargo et al. (1986). To simulate the soil dispersion by rainfall and runoff in the field, these same samples were also dispersed in distilled water. The determination of the silt and clay fractions was made using a densimeter (Soiltest, Inc.) as described by Camargo et al. (1986). The sand fraction of the samples dispersed with $\mathrm{NaOH}$ and water were separated in to ten fractions using U.S. STANDARD SIEVE SERIES numbered 18, 20, 40, 60, 80, 100, 140, 200 and 400 mesh. The statistical analysis of the sand size distribution of the sediments and soil was based on parameters

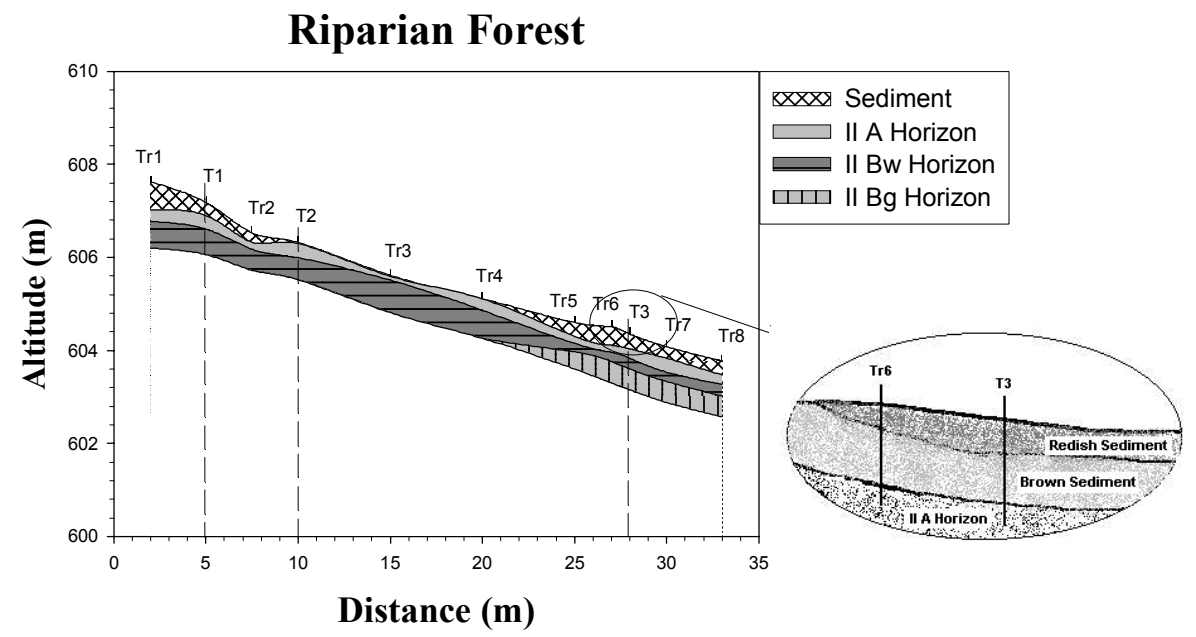

Figure 1 - Sediment and soil spatial distribution in the riparian zone transect. $\mathrm{T}=$ pit location, $\mathrm{Tr}=$ auger sampling points. 
defined by Folk \& Ward (1957) and calculated using the PHI program developed by Jong Van Lier \& VidalTorrado (1992), where phi $=-\log _{2} \mathrm{~d}$, $\mathrm{d}$ being the diameter of the soil particle in millimeters.

The detailed description of the sediment morphology and pores was performed using microscopic and image analysis of thin sections and polished blocks. For this purpose undisturbed soil samples collected from each sediment layer and soil horizon in the three pits were impregnated using a polyester resin according to Murphy (1986). The soil macro and mesoporosity was quantified using the Noesis Visilog 5.4 image analysis software. Ten $12 \times 15 \mathrm{~mm}$ areas were chosen from each soil block for image acquisition. A polarized binocular microscope (Zeiss Axioskop) with a CCD digital camera was used for image acquisition. Ultraviolet lighting (wave length $=600 \mathrm{~nm}$ ) was used for illuminating the soil porosity. The acquired images were binarized for quantification of the shape and size of pore and aggregate areas. The procedures for pore size and shape classification are described in Cooper \& VidalTorrado (2005) and Cooper et al. (2005).

\section{RESULTS AND DISCUSSION}

\section{Characterization and spatial distribution of the soil and sediments}

The morphological description of the pits showed a clear distinction between the buried soil and the sediment deposited on its surface (Figure 1). The first few meters from the border between the riparian forest and the sugar-cane field present a thick layer of sediments that thins out as it enters the forest towards the reservoir. This sediment layer initiates with a thickness of $0.60 \mathrm{~m}$ and disappears after pit T2 between 10 and $20 \mathrm{~m}$ from the border of the riparian forest. A second superficial sediment layer appears at a distance of $20 \mathrm{~m}$ from the border of the riparian forest, which differs in structure and color from the sediment layer between the upper border of the riparian forest and T2 (Table 1). This second sediment layer increases progressively in thickness reaching its maximum thickness of $0.40 \mathrm{~m}$ at a distance of $27 \mathrm{~m}$ from the border. From this point up to $33 \mathrm{~m}$, the sediment layer is thinner with a mean depth of $0.28 \mathrm{~m}$ and thins out as it approaches the reservoir. The field morphological analysis of this second sediment layer divided it into two layers, $0-0.07 \mathrm{~m}$ and $0.07-0.32 \mathrm{~m}$, due to differences in color and structure (Table 1).

The morphological characterization and distribution of sediments in the restored riparian forest revealed a significant deposition of soil material transported from the adjacent area cropped with sugar-cane. Ampontuah et al. (2005), Baudry (1997), Bertoni (1990), Correll (1997), Izidorio et al. (2005), Klapproth \& Johnson (2000), Lowrance et al. (1985) and Morgan (1997) have shown the efficiency of riparian forests in retaining and filtering sediments in different environments and land uses. An accumulation of sediments with thicknesses between $0.15 \mathrm{~m}$ and $0.50 \mathrm{~m}$ were ob-

Table 1 - Soil morphological description of pits T1, T2 and T3.

\begin{tabular}{|c|c|c|c|c|}
\hline Horizon & $\begin{array}{l}\text { Depth } \\
\text { m }\end{array}$ & $\begin{array}{c}\text { Moist Color } \\
\text { Munsell }\end{array}$ & Structure $^{1}$ & Texture \\
\hline \multicolumn{5}{|c|}{ Profile T1 - Rhodic Hapludox } \\
\hline Sediment & $0-0.28$ & $2.5 Y R 3 / 4$ & $1, \mathrm{f}, \mathrm{gr}$ & Clay \\
\hline II A & $0.28-0.57$ & $2.5 Y R \quad 3 / 4$ & $3, \mathrm{~m}, \mathrm{abk}$ & Clay \\
\hline II Bw & $0.35-1.00$ & 10R $3 / 4$ & $2-3, \mathrm{~m}-\mathrm{f}, \mathrm{sbk}$ & Clay \\
\hline \multicolumn{5}{|c|}{ Profile T2 - Rhodic Hapludox } \\
\hline Sediment & $0-0.02$ & $2.5 \mathrm{YR} 3 / 4$ & $1, \mathrm{~m}, \mathrm{sbk}$ & Clay \\
\hline II A & $0.02-0.33$ & $2.5 Y R 3 / 4$ & $2-3, \mathrm{~m}-\mathrm{co}, \mathrm{abk}$ & Clay \\
\hline II Bw & $0.33-0.42$ & $2.5 Y R 3 / 4$ & $3, \mathrm{~m}, \mathrm{abk}$ & Clay \\
\hline II Bw & $0.42-0.80$ & 2.5 YR $2.5 / 4$ & $2-3, \mathrm{~m}, \mathrm{sbk}$ & Clay \\
\hline \multicolumn{5}{|c|}{ Profile T3 - Rhodic Hapludox } \\
\hline Sediment & $0-0.07$ & $10 \mathrm{R} 3 / 4$ & $2, \mathrm{~m}-\mathrm{f}, \mathrm{gr}$ & Clay \\
\hline Sediment & $0.07-0.32$ & $2.5 \mathrm{YR} 3 / 4$ & $1, \mathrm{~m}-\mathrm{f}, \mathrm{sbk}$ & Clay \\
\hline II A & $0.32-0.52$ & 7.5YR 3/4 & $2-3, \mathrm{~m}, \mathrm{abk}$ & Sandy Clay \\
\hline II $\mathrm{AB}$ & $0.52-0.63$ & $7.5 \mathrm{YR} 4 / 4$ & $2, \mathrm{~m}-\mathrm{f}, \mathrm{sbk}$ & Clay \\
\hline II Bw & $0.63-1.00$ & $5 \mathrm{YR} 4 / 6$ & $2, \mathrm{~m}-\mathrm{f}, \mathrm{sbk}$ & Clay \\
\hline II Bg & $1.00-1.20$ & $5 \mathrm{YR} 4 / 6$ & $1, \mathrm{~m}-\mathrm{f}, \mathrm{sbk}$ & Clay \\
\hline
\end{tabular}

${ }^{1}$ Grade: 1 = weak, 2 = moderate e, 3 = strong; Size: $\mathrm{f}=$ fine, $\mathrm{m}=$ medium, $c 0$ = coarse; Type: $\mathrm{gr}=$ granular, abk = angular blocky, sbk = subangular blocky (Schoeneberger et al., 2002). 
served by Cooper et al. (1987) at the border between the cropping area and riparian forest. This sediment accumulation thins out gradually until reaching a thickness of $0.05 \mathrm{~m}$ on the alluvial plain. The results obtained contrast with those found here, in which sediments concentrated on the upper border of the riparian forest with a mean thickness of $0.30 \mathrm{~m}$ and also at the end of the forest with a similar mean thickness. No sediments were found between these two deposition sites.

The deposition hiatus that appears in the intermediate zone of the transect and the two layers of sediments at the distance of $20 \mathrm{~m}$ from the border of the forest suggest that there could have been three moments of deposition. At a first moment, before the restoration of the riparian forest, when all the transect was occupied by sugar-cane up to the border of the reservoir, in which the deposition concentrated on the alluvial plain and the sediments had no resistance before reaching the reservoir. At a second moment, which coincides with the planting and initial stages of development of the riparian forest, the soil remained temporarily and partially exposed to erosion processes that could have transported sediments down to the alluvial plain and its proximities. Finally at a third moment, when the riparian forest was fully developed and covered $100 \%$ of the soil, the retention of sediments occurred in the initial meters or upper part of the riparian forest close to the border with the sugar-cane field.
The land use changes in the area above the reservoir would mark the change in the preferential deposition location. When the sugar-cane field dominated, the alluvial plain was the preferential deposition location but after the development of the riparian forest this location was moved $27 \mathrm{~m}$ upslope within the first few meters from the border of the forest.

\section{Micromorphology and image analysis}

The soil porosity and structure quantification of the sampling points on the transect showed large differences between the sediment layers and soil horizons (Figure 2). The mean total porosity area of the sediments was more than $30 \%$ (except for the buried sediment in T3 $(0.07-0.32 \mathrm{~m})$ ) and was made up of mainly big irregular pores. In the IIA horizon a reduction of total soil porosity area was observed in which the big irregular pores were the ones that suffered the greatest changes. This evidenced a compaction process in this buried horizon that could have been caused by the successive management practices applied during the period when this area was cropped with sugarcane before the restoration of the riparian forest. The deeper horizons (B horizons) also had low porosity $(\sim 10 \%)$ but were less affected by the compaction process as evidenced by the equilibrium between rounded, elongated and irregular pores and the dominance of large pores. Two types of sediments were found in T3 (Figure 2). The superficial and reddish sediment $(0-0.07 \mathrm{~m})$ with a total porosity of $34 \%$ represented
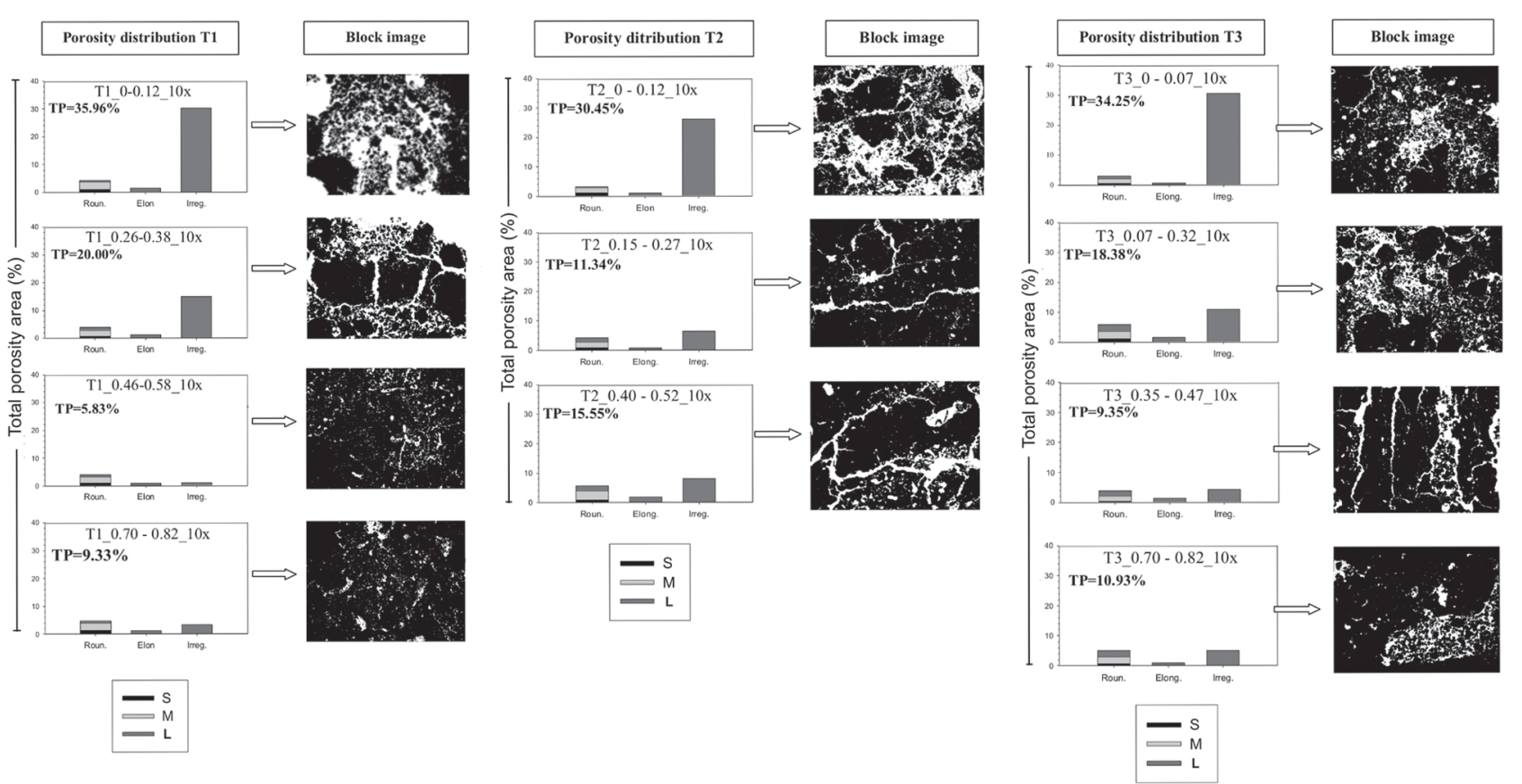

Figure 2 - Porosity distribution and binary images of the soil and sediments. ) $\mathrm{TP}=$ total pososity area; T1_0-0.12_10x = pit 1, layer from 0 to $0.12 \mathrm{~m}$ and $10 \mathrm{x}$ magnification of image; $\mathrm{S}=$ small pores; $\mathrm{M}=$ medium; $\mathrm{L}=$ large; Roum. = rounded; Elong. $=$ elongated; Irreg. = irregular pores.) 
basically by large irregular pores, presenting a small and moderate granular structure. The buried sediment (0.07-0.32 $\mathrm{m})$ has a different type of structure characterized by small and medium blocky structure and a total porosity of $18.4 \%$. In this buried sediment, the pores that presented the highest decrease were the large irregular pores. The differences in structure and pore morphology of the buried sediment could be explained by the type of land use that occupied the area (sugar-cane) when it was deposited, that could have led to a compaction process similar to the one observed in horizon IIA.

The morphological and micromorphological analysis did not show a stratified and uniform deposition process that is typical of a constant and laminar runoff flow (Laporte, 1969; Silva et al., 2004; Suguio, 1980). Conversely, the soil matrix was disorganized with no evidences of an organized stratification process. This sediment morphology without any apparent matrix organization could be the result of a random deposition process resultant from turbulent run- off fluxes that form during high energy erosion events capable of transporting large amounts of sediments. The presence of medium to large rounded quartz pebbles in T3 suggests the occurrence of one or more high energy erosive events that had enough competence to transport coarse material removed from upslope positions.

\section{Soil and sediment particle size distribution}

The results of the particle size distribution using $\mathrm{NaOH}$ as dispersing agent had a homogeneous soil along the transect with a clayey texture dominating in all the soil horizons and sediment layers (Figure 3). Among the sediment layers there were also no differences between clay, silt and sand contents. The particle size distribution of these soils determined after dispersion in water showed a decrease in the quantity of clay and an increase of the sand and silt fractions as compared to results obtained from the samples dispersed with $\mathrm{NaOH}$. This increase in the sand and silt fractions can be explained by the increase of the
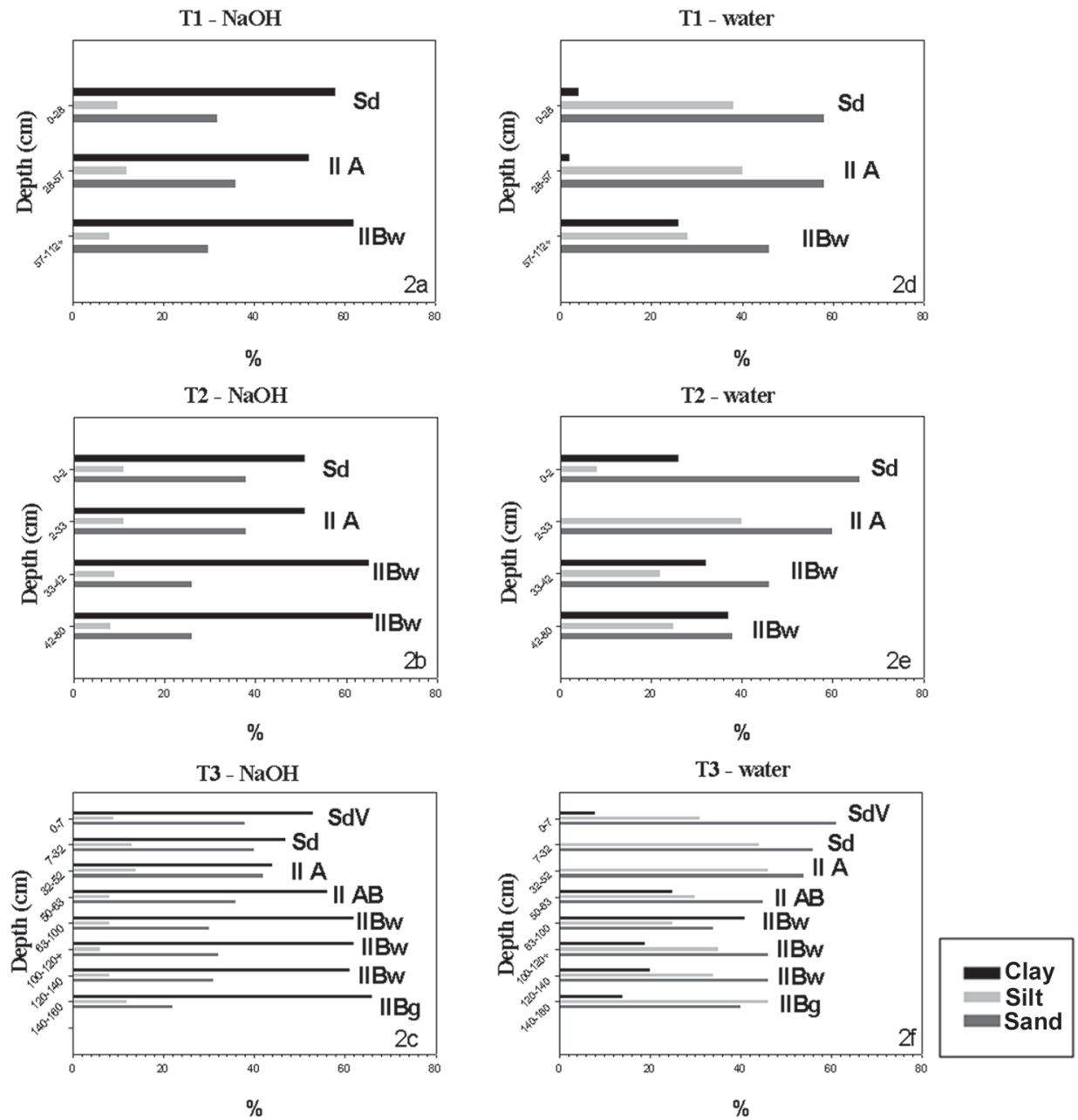

Figure 3 - Particle size distribution of T1 (pit 1), T2 (pit 2 ) and T3 (pit 3) with $\mathrm{NaOH}$ and water as dispersants. SdV redish sediment, Sd brown sediment, IIA buried A horizon, IIAB A/B buried transition horizon, IIBw B oxic horizon, IIBg B glei horizon. 
amount of clay microaggregates of sizes equivalent to medium and fine sand (Figure 3). This explains the changes in the particle size distribution of the soil and sediments between both dispersants.

The quantity of clay in the IIBw horizon was larger than in the IIA horizon in all pits. This difference increased in the samples dispersed in water. The particle size distribution determined after dispersion in water of IIA horizons in T1, T2 and T3 showed little or no water dispersible clay. The clay fraction in these horizons was all concentrated in the form of microaggregates that appear as medium and fine sand (Figure 3). This horizon could have lost all its water dispersible clay in past erosion processes or otherwise it is all concentrated in the microaggregates and flocculated with organic matter.

The observed homogeneity in the particle size distribution of the sediments contrasts with other deposition studies in riparian forests (Fullen et al., 1996) in which they found a higher concentration of the clay fraction on the footslope and further away from the sediment source. This homogeneous behavior can be explained by the presence of a clayey parent material that forms clayey soils and sediments (Ampontuah et al., 2005; Syversen \& Borch, 2005) reinforced by the process of preferential deposition. The process of preferential deposition results from the restoration of the riparian forest that altered the deposition dynamics. As discussed previously, the sediment deposition initially occurred on the alluvial plain when the land use was the sugar-cane crop and before the complete soil cover by the forest. As the trees developed, the interception of sediments increased and the deposition zone was dislocated to the upper part of the riparian forest. This process led to the deposition of clayey sediments similar to the original soil.

After the restoration of the riparian forest, an increase in the retention of water dispersible clay in the sediments was observed in all pits (Figure 3). This was not the case with the buried sediment in T3 (0.07$0.32 \mathrm{~m}$ ). In this sediment layer no water dispersible clay was found. This can be explained by the selective transport and deposition process that dominated when the soil cover in this region was sugar-cane. This process deposited the coarser fractions, including the clay microaggregates, on the alluvial plain where the kinetic energy diminished but not to a point to retain the particulate clay in suspension that could have been transported into the reservoir.

An increase in the retention of water dispersible clay in relation to the IIA horizon can be observed in the $0-0.28 \mathrm{~m}$ layer of T1, $0-0.02 \mathrm{~m}$ layer of T2 and $0-0.07 \mathrm{~m}$ layer of T3. These layers would correspond to more recent depositional events occurred after the riparian forest restoration. The evolution in the retention capacity of finer sediments was favored by the establishment of a lower energy or higher interception capacity of the depositional environment. After the substitution of the sugar-cane crop by the riparian forest, an alteration of the deposition dynamics occurred in which the tree trunks and roots (canopy and subcanopy) together with the formation of the litter bed increased the superficial rugosity reducing, consequently, the runoff velocity. The increase in soil cover favored the interception and disacceleration of the rain drops, reducing their kinetic energy and detachment force. Consequently, the particle detachment and transport was diminished and deposition occurred more intensely and closer to the sediment source. The presence of water dispersible clay in T1, T2 and T3 contrasts with the study of Syversen \& Borch (2005) in which they affirm that dispersible clay in the form of primary particles is too small to be retained in riparian zones. The relation between sediment particle size distribution and preferential areas for deposition presented by Cooper et al. (1987) and Fullen et al. (1996) are not applicable for the riparian forest presented in this study. This is explained by the change in land use on the studied transect which leads to an alteration in the sediment deposition dynamics.

\section{Statistical analyses of the sand fraction of soils and sediments}

The accumulated frequency distribution curves presented in Figure 4 show the differences, inside the soil profiles and between them, in relation to the sand size distribution. These differences are reflected on the regularity and inclination of the curves. In well sorted sediments, in which the distribution is practically normal and 5 to $10 \%$ of sand fractions other than those stated are present, the curve approaches a positive slope straight line. Irregularities in the curves, or changes in inclinations, represent changes in particle concentration of a given size.

The sand distribution determined after dispersion with $\mathrm{NaOH}$ was quite homogeneous for horizons IIA and IIBw in T1, T2 and T3. The main differences in distribution occurred in the sediment layers, especially in $\mathrm{T} 1$ that presents higher concentration of coarse sand than the subjacent horizons (Figure 4). An increase in fine and very fine sand can be observed in the sediment layer of T2 when compared to the subjacent horizons. In $\mathrm{T} 3$, the reddish sediment layer $(0-0.07 \mathrm{~m})$ has a higher concentration of medium size sand that the subjacent horizons. The brown sediment (0.07-0.32 m), for this same pit, does not present a clear differentiation in relation to the subjacent horizons in which the sand distribution is very similar to the buried soil. 
$\mathrm{T} 1 \mathrm{NaOH}$

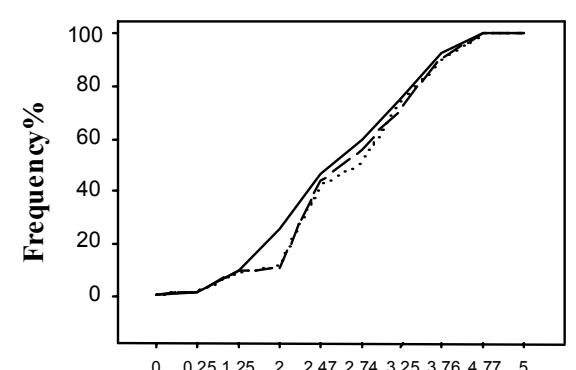

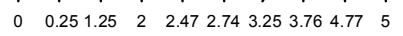

PHI scale

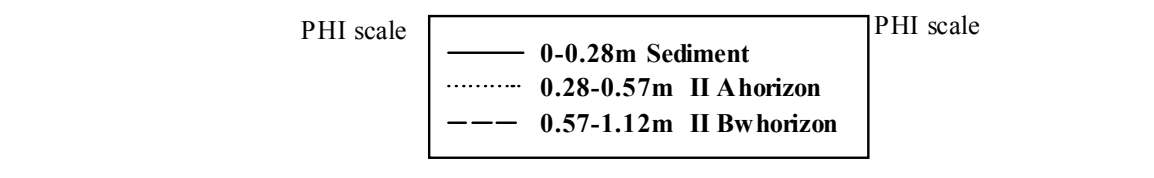

T1 water

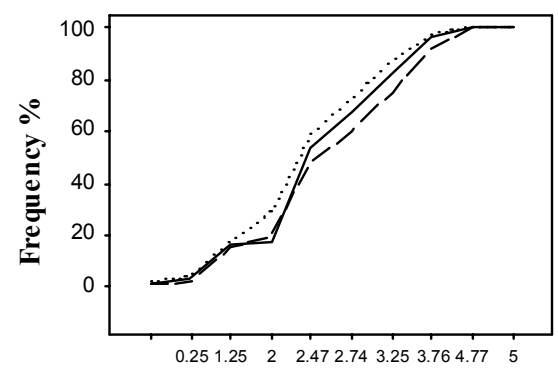

PHI scale
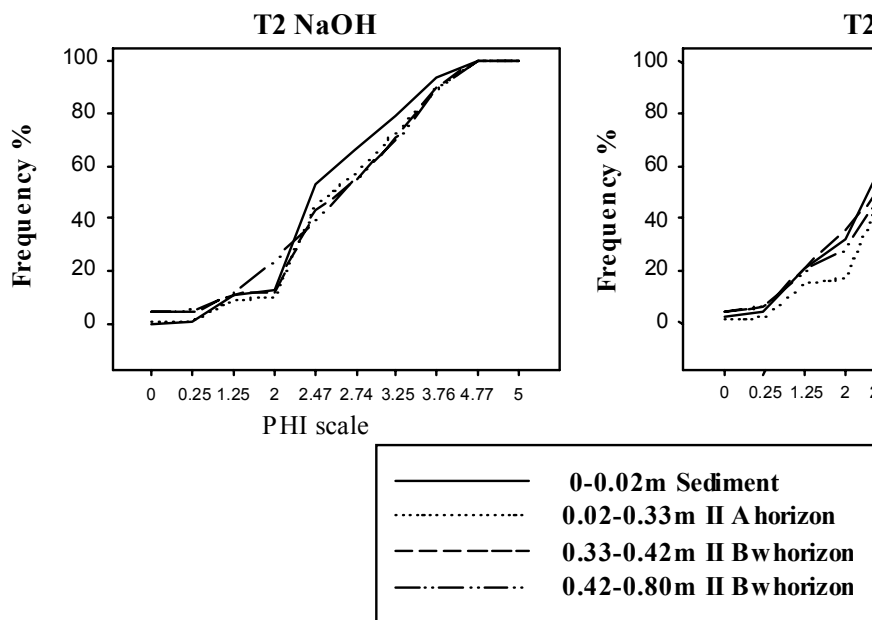

T2 water

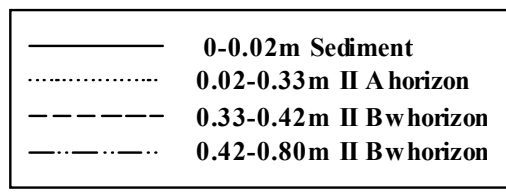

$\mathrm{T3} \mathrm{NaOH}$

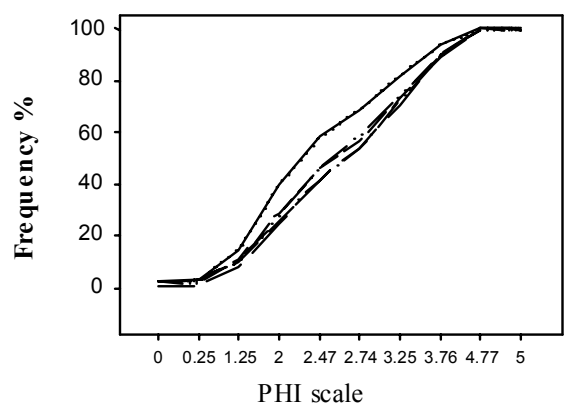

T3 water

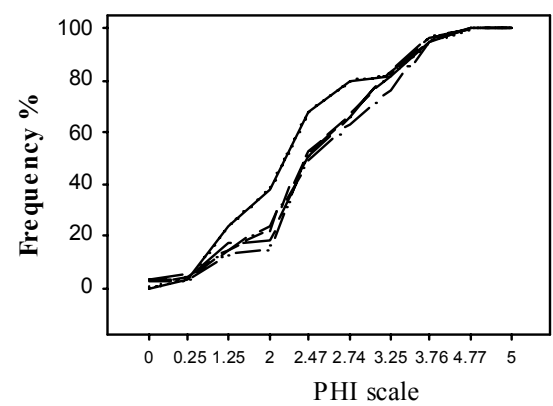

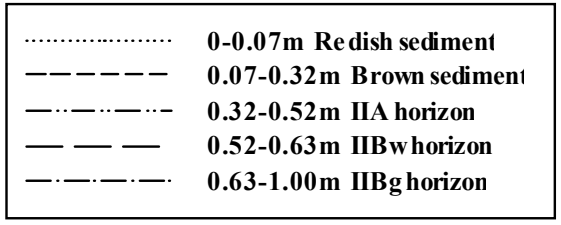

Figure 4 - Accumulated frequency distribution curves of soil and sediments at T1, T2 and T3.

The accumulated distribution frequency of the sand fraction determined after dispersion in water incorporates in the ten sand fractions the distribution of the clay microaggregates (Figure 4). The inclusion of the clay microaggregates in the sand fraction distribution changed the inclination and regularity of the accumulated frequency curves. For T1, the main differ- ence is a higher concentration of finer sand fractions in IIA as compared to the sediment layer. For T2 the contrary occurs, the sediment layer is differentiated from the subjacent material by an increase of the fine sand fractions. Finally, for T3, the difference of the reddish sediment $(0-0.07 \mathrm{~m})$ in relation to the buried soil horizons is greater than the brown sediment $(0.07$ - 


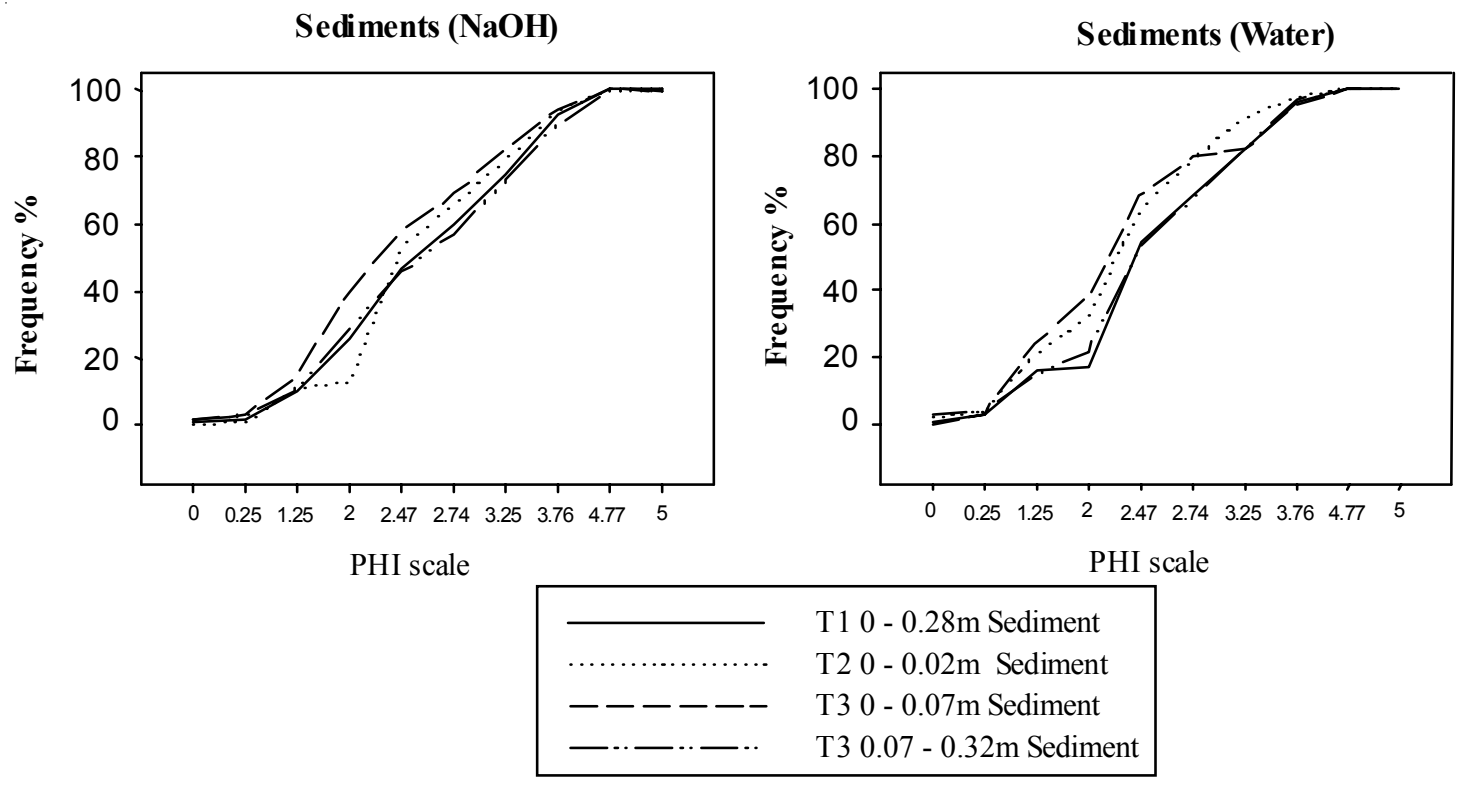

Figure 5 - Accumulated frequency distribution curves of sediments at T1, T2 and T3.

$0.32 \mathrm{~m}$ ). This last layer presents a sand distribution which is very similar to IIA and IIBw horizons. A strong tendency of clay aggregate concentration in the medium size sand fraction is observed in the reddish sediment $(0-0.07 \mathrm{~m})$ of $\mathrm{T} 3$.

The strong similarity in the accumulated frequency distribution (in $\mathrm{NaOH}$ and water) of the sediment layers of T1, brown sediment in T3, and the buried horizons of all the profiles shows that the parent material of these sediments belong to the local soil (Figure 5). For T2, the parent material of the sediment layer is also the local soil but the accumulated frequency distribution shows the predominance of finer sand fractions that could indicate a differentiated selection process of deposition. This is easy to understand when the sediment layer in T2 marks the end of the sediment deposited in the first meters of the riparian forest (Figures 1 and 4). The alteration in the shape of the curve of the reddish sediment layer $(0-0.07 \mathrm{~m})$ indicates a differential selection of the sediment there deposited. This sediment could probably have been deposited during an erosive event of medium intensity that permitted the deposition of finer material.

\section{CONCLUSIONS}

The increased deposition of sediments in the riparian zone was favored by the restoration of the riparian forest. The change in the location of sediment deposition depends on land use changes and the stage of development of the riparian forest. The morphology and distribution of the sediments suggest that these could have been deposited during high intensity erosive events. The absence of a regular and uniform deposition pattern suggests that the sediment deposition results from runoff with a turbulent flux that produces sediments moderately to poorly selected, not stratified and with an irregular morphology.

\section{ACKNOWLEDGEMENTS}

To CAPES and CNPq for financial support and scholarship.

\section{REFERENCES}

AMPONTUAH, E.O.; ROBINSON, J.S.; NORTCLIFF, S. Assessment of soil particle redistribution on two contrasting cultivated hillslopes. Geoderma, v.132, p.324-343, 2005.

BAUDRY, J. Buffer zones and farming systems. In: HAYCOCK, N.E.; BURT, T.P.; GOULDING, K.W.T.; PINAY, G. (Ed.). Buffer zones: their processes and potential in water protection. Harpenden: Quest Environmental, 1997. p.275-282.

BERTONI, J.; LOMBARDI NETO, F. Conservação do solo. São Paulo: Ícone, 1990. 355p.

BOULET, R.; CHAUVEL, A.; HUMBEL, F.X.; LUCAS, Y. Analyse structurale et cartographie en pédologie: I - Prise en compte de l'organisation bidimensionelle de la couverture pédologique: les études de toposéquences et leurs principaux apports à la connaissance dês sols. Cahiers ORSTOM. Serie Pedologie, v.19, p.309-321, 1982.

CAMARGO, O.A. de; MONIZ, A.C.; JORGE, J.A.; VALADARES, J.M.A.S. Métodos de análise química, mineralógica e física de solos do Instituto Agronômico de Campinas. Campinas: IAC, 1986. 94p. (Boletim Técnico, 106).

COOPER, M.; VIDAL-TORRADO, P. Caracterização morfológica, micromorfológica e físico-hídrica de solos com horizonte $\mathrm{B}$ nítico. Revista Brasileira de Ciência do Solo, v.29, p.581$595,2005$.

COOPER, M.; VIDAL-TORRADO, P.; CHAPLOT, V. Origin of microaggregates in soils with ferralic horizons. Scientia Agricola, v.62, p.256-263, 2005. 
COOPER, J.R.; GILLIAM, J.W.; DANIELS, R.B.; PORBAGE, W.P. Riparian areas as filters for agricultural sediments. Soil Science Society of America Journal, v.51, p.416-420, 1987.

CORRELL, D.L. Buffer zones and water quality protection: general principles. In: HAYCOCK, N.E.; BURT, T.P.; GOULDING, K.W.T.; PINAY, G. (Ed.). Buffer zones: their processes and potential in water protection. Harpenden: Quest Environmental, 1997. p. 7-20.

DOUGLAS, I. Sediment transfer and siltation. In: CLARK, W.C.; TURNER, B.L.; KATES, R.W.; RICHARDS, J.; MATHEWS, J.T.; MEYER, W. (Ed.). The earth as transformed by human action. Cambridge: Cambridge University Press, 1990. p.215234.

EMPRESA BRASILEIRA DE PESQUISA AGROPECUÁRIA. Sistema brasileiro de classificação de solos. Rio de Janeiro: Embrapa Solos, 2006. 412p.

FOLK, R.L.; WARD, W.C. Brazos river bar: a study on the significance of grain-size parameters. Journal of Sedimentary Petrology, v.27, p.3-26, 1957.

FULLEN, M.A.; YI, Z.; BRANDSMA, R.T. Comparison of soil and sediment properties of a loamy sand soil. Soil Technology, v.10, p.35-45, 1996.

IZIDORIO, R.; MARTINS FILHO, M.V.; MARQUES JR., J.; SOUZA, Z.M.; PEREIRA, G.T. Perdas de nutrientes por erosão e sua distribuição espacial em área sob cana-de-açúcar. Engenharia Agrícola, v.25, p.660-670, 2005.

JONG VAN LIER, Q. de; VIDAL-TORRADO, P. PHI: Programa de Microcomputador para Análise Estatística da Granulometria de Sedimentos. Revista Brasileira de Ciência do Solo, v.16, p.277-281, 1992 .

KLAPPROTH, J.C.; JOHNSON, J.E. Understanding the science behind riparian forest buffers: effects on water quality. Virginia: Virginia Cooperative Extension, 2000. 24p.

LAL, R. Agronomic consequences of soil erosion. In: PENING DE VRIES, F.W.T.; AGUS, F.; KERR, J.M. (Ed.). Soil erosion at multiple scales: principles and methods for assessing causes and impacts. London: CAB International, 1998. p.149-160.

LAPORTE, L.F. Ambientes antigos de sedimentação. São Paulo: Edgard Blücher, 1969. 145p.

LEMOS, R.C.; SANTOS, R.D. Manual de descrição e coleta de solo no campo. 4.ed. Viçosa: SBCS, 2002. 83p.

LOWRANCE, R.; LEONARD, R.; SHERIDAN J. Managing riparian ecosystems to control nonpoint pollution. Journal of Soil \& Water Conservation, v.40, p.87-91, 1985.
MORGAN, R.P.C. Erosión y conservación del suelo. Madrid: Ed. Mundi-Prensa, 1997. 343p.

MURPHY, C.P. Thin section preparation of soils and sediments. Berkhamsted: A.B. Academic Publishers, 1986. $149 \mathrm{p}$.

RODRIGUES, R.R.; LEITÃO-FILHO, H.F.; CRESTANA, M.S.M. Revegetação do entorno da represa de abastecimento de água do município de Iracemápolis/ SP. In: SIMPÓSIO NACIONAL DE RECUPERAÇAO DE ÁREAS DEGRADADAS, Curitiba, 1992. Anais. Curitiba: FUPEF, 1992. p.406-414.

RODRIGUES, R.R.; MARTINS, S.V.; BARROS, L.C. Tropical rain forest regeneration in an area degraded by mining in Mato Grosso state, Brazil. Forest Ecology and Management, v.190, p.323333,2004

SCHOENEBERGER, P.J.; WYSOCKI, D.A.; BENHAM, E.C.; BRODERSON, W.D. Field book for describing and sampling soils, Version 2. Lincoln: Natural Resources Conservation Service, National Soil Survey Center, 2002. 254p.

SILVA, A.C.; VIDAL-TORRADO, P.; CORTIZAS, A.M.; RODEJA, E.G. Solos do topo da Serra São José (Minas Gerais) e suas relações com o paleoclima no Sudeste do Brasil. Revista Brasileira de Ciência do Solo, v.28, p.455-466, 2004.

SOIL SURVEY STAFF. Keys to soil taxonomy. 5.ed. Blacksburg: Soil Management Support Service, 1997. (Technical Monograph, 19).

SPAROVEK, G.; RANIERI S., B.L.; GASSNER, A.; DE MARIA I., C.; SCHNUG, E.; SANTOS, R.F.; JOUBERT, A. A conceptual framework for the definition of the optimal width of riparian forests. Agriculture, Ecosystems and Environment, v.90, p.169-171, 2002.

SUGUIO, K. Rochas sedimentares: propriedades, gênese e importância econômica. São Paulo: Edgard Blücher, 1980. 500p.

SYVERSEN, N.; BORCH, H. Retention of soil particle fractions and phosphorus in cold-climate buffer zones. Ecological Engineering, v.25, p.382-394, 2005.

Received September 12, 2006

Accepted June 22, 2007 